\title{
Islamic Shari'ah Rulings on New Reproductive Choices
}

\section{Hossam E. Fadel, M.D. Ph.D., F.A.C.O.G.}

Clinical Professor, Department of Obstetrics and Gynecology, The Medical College of Georgia, Augusta, GA. Director of Maternal-Fetal Medicine, University Hospital, Augusta, GA.

Abstract: Infertility is a serious hardship. There have been several advancements in its management. A major breakthrough in 1978 was the successful achievement of pregnancy and the birth of a girl as a result of In Vitro Fertilization (IVF). That success led to several technological innovations that heralded a new era of "Non Coital Reproduction". These methods are collectively known as "Assisted Reproductive Technologies (ARTs)." These are now available to women all across the USA and in many other countries. Thousands of couples are achieving pregnancies through the use of ARTs every year. Most of these couples would otherwise never have achieved pregnancies.

Although this is a welcome addition to the medical armentarium, there are several unresolved ethical, societal and religious concerns about their applications, especially in regards to the more recent applications of IVF.

A brief account of "normal" procreation and the basic principles of ARTs are given. Then the shar $\vec{i} a$ (Islamic law) principles that guide us in deciding the acceptability of these technologies will be discussed. Then the rulings that have been agreed upon by Islamic scholars will be given. Briefly stated, Islam not only allows but also encourages married couples to seek treatment of infertility, including the use of ARTs. However, certain limits cannot be crossed. The Islamic principles that identify these limits are 1) a valid marriage contract; 2) preservation of lineage including adopted offspring; 3 ) surrogacy is prohibited and the "birth mother" is the mother; and 4) gametes are not to be donated.

Key words: Assisted Reproductive Technologies, In Vitro Fertilization, Embryo transfer, egg donation, embryo donation, adoption, surrogate motherhood, Islamic jurisprudence, Shari'ah, Islamic perspective.

\section{Introduction}

The inability of a married couple to conceive or have a child can be a devastating experience.

Although this can be caused by infertility, repeated miscarriages/pregnancy losses or certain diseases/genetic conditions in either or both husband and wife that make pregnancy contraindicated or too risky would lead to the same result. However, attention is generally focused on the infertile couple. Infertility is roughly the result of female factors in $1 / 3$, male factors in $1 / 3$, and combined male and female factors in the remaining $1 / 3$ of the cases. In many cases, the cause is presumptive and can not

Presented at the Annual IMANA Convention San Francisco, CA, July 2005

Reprint Requests: Hossam E. Fadel, M.D. 1348 Walton Way, Suite 5500, Augusta, GA 30901 be identified.

After the investigation and conventional treatment of infertility, many couples will still be unable to have a pregnancy by the natural means (coital reproduction). Now there are several methods of non-coital reproduction available to such couples.

The oldest and best known of these methods is artificial insemination (AI). AI may have been used in folk medicine for a long time; however, it only became recognized as a form of medical treatment in the last 40-60 years. Initially AI was practiced using the husband's sperm. When it was thought that the husband's sperm quality was poor (few/immotile sperms), several samples were collected and concentrated and injected into the wife's uterus under con- 
trolled conditions (AIH). Gradually, the concept of donated semen became acceptable. The semen is collected from a selected donor and then inseminated in the wife at the time of ovulation, a process called artificial insemination donor (AID). Donors are selected based on general health, race, other characteristics, blood group, and are screened for the absence of transmittable disease, both infectious and genetic. Because of the Acquired Immune Deficiency Syndrome (AIDS) epidemic, it is now customary to freeze semen. After six months, when the donor is retested for the Human Immune Deficiency virus (HIV) and is found to be negative, then the semen is used.

Adoption is another method used by infertile couples. It is now much more difficult to accomplish because of the significant decrease in the number of children available for adoption in the U.S.A. This resulted from the wide use of contraception, the availability of abortion on demand, and the fact that unwed motherhood and single parent families became socially acceptable. Now, many couples seek to adopt children from overseas.

A new era of reproductive technology was heralded by the demonstration that human ova (eggs) can be retrieved from the woman's ovary and fertilized in vitro, i.e., in a Petri dish outside the human body and the fertilized egg can then be transferred to the uterus (embryo transfer or ET) where it can implant and continue to develop into a fetus. ${ }^{1,2}$ Technically, this procedure is called "In-Vitro FertilizationEmbryo Transfer" (IVF-ET), and the first baby born using this method (first test tube baby) was in 1978 in the UK. ${ }^{3}$ Several other reports of successful births using this technique appeared shortly thereafter, both in the United States and other countries. ${ }^{4-6}$ The rapid evolution of this technique has resulted in a plethora of possibilities of non-coital reproduction.

Sperms have been known for a long time to survive freezing through a process called cryopreservation and when thawed can still fertilize an egg. The recent demonstration that fertilized ova; zygotes and blastocysts (pre-embryos) can also be frozen for years and yet when thawed can start dividing and growing, and if implanted in a uterus, can continue to develop into a fetus was another milestone and created additional avenues of biotechnical parenting. ${ }^{7}$ More recently, the unfertilized ova were also demonstrated to withstand long periods of freezing (see below). These different methodologies are now referred to as Assisted Reproductive Technologies (ARTs).

\section{Normal (Coital) Reproduction}

In a normally ovulating woman, each month at midcycle, one mature oocyte is released from the ovary and is captured by the fimbriated end of the fallopian tube where it starts its journey toward the uterus. During sexual intercourse, millions of spermatozoa are deposited in the vagina. Only a portion of these spermatozoa enter the uterus, and only a few dozen reach the ampullary portion of the fallopian tube where they encounter the oocyte. Only one sperm penetrates the oocyte, and fertilization occurs. The resulting zygote continues its journey down the fallopian tube for 2-3 days and, during its transit, continues to divide into approximately $8-16$ cells. The pre-embryo then enters the uterus in the blastocyst stage and after 2-3 days it implants itself in the uterus and grows over the next 39 weeks. Term pregnancy is 40 weeks.

\section{InVitro Fertilization-Embryo Transfer}

IVF-ET was originally designed for women with bilateral tubal block and the idea was to bypass the tubes. Briefly described, the maturing ova are retrieved from the woman immediately before ovulation and fertilized in Petri dish with sperm from the woman's husband. Then, after two to three days, when the fertilized egg is at the four to eight cell stage, it is transferred into the uterus. Three or four days later, this small cluster of cells (blastocyst) implants itself and then grows over the next 39 weeks into a fully formed fetus. A more detailed description follows.

\section{A. Stimulated Cycle}

Agents that induce ovulation are given to the wife both to promote the simultaneous maturation of a number of oocytes and to cause ovulation to occur at a particular time of the day to facilitate egg retrieval. $75 \%$ of stimulated cycles are successful, i.e., result in mature ova. ${ }^{6}$ 
B. Oocyte Retrieval

Oocyte Retrieval is planned slightly before actual ovulation. Initially, it was done through laparoscopy. ${ }^{8}$ More recently, it became routine to retrieve the eggs through ultrasonically guided needle aspiration either by the transabdominal-transvesical, the transvaginal or transurethral route. ${ }^{9}$ Usually 5-8 eggs are retrieved. Egg retrieval is successful $95 \%$ of the time.

\section{Fertilization}

Once retrieved, the oocytes are evaluated for the degree of maturation. "Mature" oocytes are incubated for 5-6 hours, whereas immature oocytes are incubated for 24-26 hours. Husband's sperm are washed in a special medium and then capacitated (made more likely to fertilize). Typically, 50,000100,000 sperms are added to the culture medium containing the oocytes. If fertilization is successful, cleavage starts, and a 2-8 cell zygote is formed in 4872 hours after fertilization.

\section{Embryo Transfer:}

The 2-8 cell pre-embryo is then aspirated into a fine catheter that is introduced through the cervical canal until it is within $1-2 \mathrm{~cm}$ of the uterine fundus and then the pre-embryos are injected into the uterine cavity. Usually up to 2-3 pre-embryos are transferred to maximize the chance of a successful implantation/pregnancy. ${ }^{10} \mathrm{~A}$ "chemical pregnancy" is said to have occurred if the pregnancy test becomes positive, but a "clinical pregnancy" is said to have occurred when ultrasonography shows an embryo with cardiac activity, usually 4-5 weeks after the transfer.

Usually fertilization produces more pre-embryos than are considered safe to replace (to avoid high order multiple pregnancies, i.e. triplets or more). Many IVF-ET clinics now have a policy for cryopreserving the extra pre-embryos. ${ }^{7}$ These can be thawed later and transferred to the patient in later cycles, thus, avoiding the cost and inconvenience of going through additional stimulation/retrieval cycles. These can also be donated to other couples (see below) or donated to research.

Three variations on the theme described above are being used:
1. In cases where the tubes are patent and of normal appearance, both the sperms and ova are deposited into the fallopian tube (usually two oocytes in each tube) to allow fertilization to occur in vivo, instead of in vitro. The gametes are deposited through laparoscopy and the procedure is called Gamete Intra-Fallopian Transfer (GIFT). ${ }^{11}$

2. After IVF, the fertilized ovum (zygote) is directly transferred through laparoscopy in the ampullary portion of the fallopian tube, a procedure called Zygote Intra-Fallopian Transfer (ZIFT).12,13 Both procedures require at least an intact fallopian tube and therefore cannot replace the routine IVF.

3. In cases of male infertility with severe oligosper$\mathrm{mia} /$ azospermia, if one can get even a few sperms, these are injected directly, using micromanipulation techniques, into the ovum to effect fertilization, a procedure called intracytoplasmic sperm injection (ICSI). This procedure is used successfully in many centers with good results. The factors that affect its outcome have been recently reviewed. ${ }^{14}$

Almost all clinics have to provide the three abovedescribed alternatives, in addition to the "usual" IVF-ET. On the average it costs $\$ 6,000$-to $\$ 8,000$ per cycle. In the USA, ARTs are mostly not covered by health insurance and are really available only to the well-to-do who can pay significant amounts of cash, mostly in advance.

It is noteworthy to mention that in any of above procedures, donor sperm or donor ova can be used instead of those of the husband and wife respectively. Moreover, donated pre-embryos can be used. ${ }^{15}$

\section{Oocyte Donation}

Although oocyte donation is based on the same principle as semen donation, it became a practical alternative only recently. In IVF stimulation cycles, extra eggs are available, and women undergoing gynecologic surgery, if timed properly, can be an additional source of eggs (retrieved during the surgery).

Moreover, with the increasing ease and safety of egg retrieval by ultrasonically guided needle aspiration in an office setting under local anesthesia, it is possible that women undergo the procedure for the sole purpose of egg donation. In fact there are programs 
now available where they pay "volunteers" to donate the eggs $(\$ 5,000$ or more for each cycle), while other volunteers donate the eggs (free of charge) for an infertile family member or friend. The donated oocyte can then be fertilized in vitro by a "husband's" sperm and then transferred to the uterus of the "wife" (recipient). It is essential that this process is planned so that the menstrual cycles of the donor and recipient women are synchronized, and that the transfer of embryo occurs on day 17-19 of the recipient's cycle (to be receptive for implantation). ${ }^{16}$ In this scenario, there is a biologic genetic link with the rearing father and a biologic gestational link with the rearing mother, but the child lacks the genetic tie with the gestational rearing mother (and lack of rearing by the genetic mother).

Freezing of oocytes has been recently successfully accomplished. However, the survival rate initially was low. ${ }^{17-9}$ Cryopreservation may have deleterious effects on oocyte structures, for example, zona pellucida, cortical granules, spindle microtubules, cytoplasmic microfilaments and organelles. The use of newer techniques and the development of different media have improved the ability of the thawed ova to be fertilized. ${ }^{20}$ The live birth rate using thawed cryopreserved ova in IVF procedures has been improved. ${ }^{21}$

Nationally, the women who use donated eggs in IVF procedures have increased from $8 \%$ in 1995 to $11 \%$ in 2002. More than 13,000 egg donation procedures were performed in $2002 . .^{22}$

\section{Embryo Donation (ED)}

A variation of the above theme is Embryo Donation. ${ }^{15}$ The fertile (donor) woman is artificially inseminated by the "husband's" sperm. Three to five days later the uterus is flushed out with a special catheter and the embryo is retrieved and transferred to the wife's uterus provided that her cycle has been synchronized with the donor's cycle. One risk of this procedure is that the embryo is not retrieved and implants in the donor's uterus. Embryo donation is also possible in another way. It is now customary that the extra pre-embryos obtained at each IVF cycle are frozen (cryopreserved). They can later be donated to another couple. The pre-embryo is thawed and transferred to the recipient at the appropriate time of the cycle. In this scenario, while the "wife" is the "gestational" parent, the child is not genetically linked to either of his rearing parents.

\section{Surrogate Motherhood}

In this "technique," a couple commissions another woman to carry their baby and deliver it and then give it back to the commissioning couple, who would legally adopt that child. In this kind of arrangement there are three types of parents: the genetic parent, the gestational parent, and the rearing parent.

\section{There are two types of surrogacy:}

1. Complete (gestational) surrogacy. Wherein the sperm and ova are those of the commissioning couple. IVF is achieved and the embryo is then transferred to the uterus of the surrogate mother. In this scenario, there will be the biological/rearing commissioning couple and a biological/birth surrogate mother. A variation of this would be that the implanted pre-embryo is donated by a couple other than the commissioning couple. In this scenario, there will be a rearing commissioning couple, biological parent(s) who donated the gamete/preembryo and a birth/surrogate mother.

2. Partial surrogacy: Wherein the surrogate mother is inseminated artificially with the commissioning father's sperm or his sperm is used to fertilize retrieved egg(s) from the surrogate mother in vitro and then the embryo(s) is (are) transferred to her uterus. In partial surrogacy, the surrogate provides both the egg and gestation, and therefore she is the biological/genetic as well as the biological/birth mother. The female rearing parent will not have even a genetic or biological link with the offspring. The offspring is genetically linked to the commissioning father.

The registry of the American Society for Reproductive Medicine/Society for Assisted Reproductive Technology (ASRM/SART) was last updated for the year 2000. They collected data from 383 IVF-ET participating programs in the USA. They reported initiating 99,989 cycles of ART treatment. Of these there were 73,406 cycles of fresh non-donor IVF, $46.6 \%$ of these involved intracytoplasmic sperm injection (ICSI) with a delivery rate per retrieval of $29.9 \%$. There were 549 cycles of GIFT with a delivery 
rate per retrieval of $24.7 \%$. There were 763 cycles of ZIFT with a delivery rate per retrieval of $29.9 \%$. There were 13,083 frozen embryo transfer procedures with a delivery rate per transfer of $20.4 \%$. Including all procedures involving non-donor as well as donated gametes or embryos and 1,200 cycles using a host uterus (surrogate), there were 25,394 deliveries resulting in 35,345 neonates of which 35,031 were liveborn and 314 were stillborn. ${ }^{22,23}$

\section{Islamic Perspective}

Allah reminds human beings that having spouses and offspring are two of His significant bounties.

Allah says in the Glorious Qur'an:

Wealth and progeny are allurements of the life of this world ...24

And Allah has made for you mates (and companions) of your own nature, and made for you, out of them, sons and daughters and grandchildren ...25

Islam recognizes the inherent desire of married couples to have their own children:

And those who pray, 'Our Lord! Grant unto us wives and offspring who will be the comfort of our eyes ... ${ }^{26}$

The inability to have children (infertility) is one of the serious hardships that a married couple endures. However, it is clearly stated in the Qur'an that infertility is ordained by Allah and will happen to certain couples the same as other hardships/disasters which afflict humankind now and then:

To Allah belongs the dominion of the heavens and the earth. He creates what He wills: He bestows (children) male or female according to His will (and plan). Or He bestows both males and females and He leaves barren whom $\mathrm{He}$ wills, for He is full of knowledge and power. ${ }^{27}$

Islam recognizes this hardship and gives the examples of two Prophets, Ibrahim and Zakariyya (Peace be upon them), who were infertile and yearned to have children. They were specifically mentioned in the Qur'an as having prayed for Allah to grant them children:

Oh my Lord! grant me a righteous (son). So We gave him the good news of a boy ready to suffer and forebear. ${ }^{28}$

There did Zakariyya pray to his Lord, saying: ' $\mathrm{O}$, my Lord! Grant unto me from You progeny that is pure. For you are He that hears prayers. ${ }^{29}$

Thus, a Muslim is enjoined to ask Allah to relieve his/her distress of whatever nature, including infertility. Moreover, Muslims are enjoined to seek treatment for all "diseases." Prophet Muhammad (PBUH) said, "Servants of Allah, seek medical treatment because Allah did not create a disease without creating a cure thereof except one, that is senility." ${ }^{30}$

Thus, infertile couples can and should undergo all possible medical therapies/interventions to achieve a pregnancy or a child of their own as long as the method does not contradict any Islamic law or principle. Moreover, it is incumbent on the couple to understand that their wish may not be granted or their prayer may not be answered, as in any other situation when man is asking Allah for help.

Preservation of the family unit is of utmost importance in Islam. Laws governing morality, sexual behavior, marriage, relation between husband and wife, and children are abundantly clear and detailed. Family laws such as whom one can and cannot marry, the persons who are considered strangers to a woman and those who are not, laws of inheritance which are very specific about the rights of each different family relation are absolutely dependent on the proper lineage. Therefore, preservation of lineage is of great significance in Islam. Any obscuring of this lineage adversely affects these laws.

Verses that stress the significance of lineage include:

And out of [your spouses], he created sons and daughters and grandchildren and provided for you sustenance of the best ... ${ }^{25}$

... established relations of lineage and marriage .... 
Traditional methods of treating infertility such as hormonal therapy, ovulation induction, correction of blocked fallopian tubes or intrauterine insemination using husband's sperm are non-controversial from the religious point of view. The lineage is preserved and the wife/mother gives birth to the child.

It is clear that the newer ARTs raised a lot of questions and uncertainties. As they are new, Islamic jurists had to derive rulings that pertain to them. The main sources of Islamic jurisprudence, the Shar $\vec{I} a$, are based on the teachings of the Glorious Qur'an and the Prophetic sunnah (traditions) and sayings (ahādith). When there is no specific mention of the questioned item, jurists have to rely on ijtihad. The different methodologies of ijtithad that Islamic jurists follow include:

1. Qiyās (anaological reasoning)

2. Istiḩsān (juristic preference)

3. Maslaha mursala (public interest)

4. Sadd al-dharä $i$ ' (blocking of means)

5. 'Ādatt and 'urf (customary practice)

6. Istișhāb (presumption of continuity)

All along the jurist making ijt thad must keep in mind the basic objectives of shar $\vec{i} a$, i.e., the protection and preservation of life, religion, intellect, progeny and property. ${ }^{32}$ Protection of progeny is most closely related to the topic under discussion.

In medical issues, it is important to have the opinion of the medical scientist/practitioners. Such is best accomplished in joint meetings where the medical personnel educate the Muslim scholars about the rationale and methods used in the medical practice of the issue while the 'Ulam $\vec{a}$ (Muslim scholars) educate the medical professionals on the figh (jurisprudence) issues related to the topic. The participants can then come up with the appropriate ruling. Several such conferences have been organized by several bodies, prominent among which is the Islamic Organization for Medical Sciences based in Kuwait. Its last conference was convened in Cairo, Egypt, in December 2004.33

The following is an outline of the Islamic rulings on ARTs that came out of these conferences. ${ }^{34-6}$
New "Assisted Reproductive Technologies" (ARTs) are only allowed if they are performed in the context of an intact marriage, i.e., during the life span of marriage, while both partners are alive, using the husband/wife gametes, and the resulting embryo is implanted and carried in the wife's womb.

Within this context the following is permissible:

1. Artificial insemination with the husband's sperm (i.e. AIH).

2. IVF-ET (including GIFT and ZIFT and ICSI) using the husband's and wife's gametes and the wife's uterus.

3. In case a wife is threatened with loss of ovarian function from a gynecologic disease or from the use of chemotherapy/radiotherapy to treat a non-gynecologic cancer, her ova may be collected from her ovaries prior to the anticipated loss, fertilized by her husband's sperm and then cryopreserved for future use (to be implanted in her uterus while she is still married to the same husband). Under the same circumstances, an unmarried woman, thanks to the new technology available, her ova can be collected and cryopreserved without being first fertilized.

4. Surrogacy is prohibited. ${ }^{34-7}$ Confusion of lineage is inherent in all types of surrogacy. In addition, there are inherent legal concerns, especially when a dispute arises among the prospective parents. Further, there are ethical concerns. Surrogacy seems to commodify motherhood. It reduces it from a value to a price. ${ }^{38}$ Finally, there is a specific definition of the mother in Islam that surrogacy contradicts:

... None can be their mothers except those who give them birth ...39

And Allah has brought you out from the wombs of your mothers while you know nothing. And He gave you hearing, sight, and hearts that you might give thanks (to Allah). ${ }^{40}$

He creates you in the wombs of your mothers: creation after creation in three veils of darkness. Such is Allah your Lord. 41 
We have enjoined on man kindness to his parents; in pain did his mother bear him and in pain did she give him birth ... ${ }^{42}$

In fact, the Arabic word meaning "to give birth" is walad, and for "mother" is wālida, i.e. the one who gives birth.

In cases where the permissible procedures have failed or could not be used, adoption should be considered as the best option. Thousands of Muslim orphans/refugees are without shelter or support. These children can be adopted, and adoption would constitute a very significant act of charity as it would not only ensure their survival, but also their upbringing as Muslims. However, one should realize the limitations of adoption in Islam, i.e., that these children should not be legally considered as one's own children, specifically in relation to laws of marriage and inheritance.

... nor has He made your adopted sons, your sons. Such is (only) your (manner or) speech by your mouths. But Allah tells (you) the truth, and He shows the right way. Call them by (the names of) their fathers; that is more just in the sight of Allah. But if you know not their fathers' (names), call them your brothers in faith ... ${ }^{43}$

How Islamically acceptable adoption can be carried out in the U.S.A. is beyond the scope of this paper.

It behooves us Muslim health professionals to understand these rulings and educate our community in this important topic. In particular, Muslim health care providers involved in infertility treatment when dealing with Muslim patients should inform them of these rulings and give them the best advice.

\section{References}

1. Edwards RG, Bavister BD, Steptoe PC. Early stages of fertilization in vitro of human oocytes matured in vitro. Nature 1969 Feb 15;221(181):632-5.

2. Edwards RG, Steptoe PC, Purdy JM. Establishing full-term human pregnancies using cleaving embryos grown in vitro. Br J Obstet Gynaecol 1980 Sep;87(9):737-56.

3. Steptoe PC, Edwards RG. Birth after the reimplantation of the human embryo. Lancet 1978 Aug
12;2(8085):366.

4. Lopata A, Johnston IW, Hoult IJ, Speirs AI.

Pregnancy following intrauterine implantation of an embryo obtained by in vitro fertilization of a preovulatory egg. Fertil Steril 1980 Feb;33(2):117-20. 5. Trounson A, Wood C. Extracorporeal fertilization and embryo transfer. Clin Obstet Gynaecol 1981 Dec;8(3):681-713.

6. Trounson AO, Leeton JF, Wood C, Webb J, Wood J. Pregnancies in humans by fertilization in vitro and embryo transfer in the controlled ovulatory cycle. Science 1981;212:681-2.

7. Trounson A, Mohr L. Human pregnancy following cryopreservation, thawing and transfer of an eightcell embryo. Nature 1983;305:707-9.

8. Renou P, Trounson AO, Wood C, Leeton JF. The collection of human oocytes for in vitro fertilization. I. An instrument for maximizing oocyte recovery rate. Fertil Steril 1981;35:409-12.

9.Wikland M, Nilsson L, Hansson R, Hamberger L, Janson PO. Collection of human oocytes by the use of sonography. Fertil Steril 1983;39:603-8.

10. Leeton J, Trounson A, Jessup D, Wood C. The technique for human embryo transfer. Fertil Steril 1982;38:156-61.

11. Asch RH, Ellsworth LR, Balmaceda LR, Wong PC. Pregnancy after translaparoscopic gamete in-trofallopian transfer. Lancet 1984;2:1034-5.

12. Devroey P, Braeckmans P, Smitz J et al:

Pregnancy after translaparoscopic zygote intrafallopian transfer in a patient with sperm antibodies. Lancet 1986;1:1329.

13. Palermo G, Joris H, Devroey P, Van Steirteghem AC. Pregnancies after intracytoplasmic injection of single spermatazoon into an oocyte. Lancet 1992;340:17-8.

14. Lewis S, Klonoff-Cohen $\mathrm{H}$. What factors affect intracytoplasmic sperm injection outcomes? Obstet Gynecol Surv 2005;60:111-23.

15. Seibel MM: A new era in reproductive technology. In vitro fertilizaion, gamete intrafallopian transfer, and donated gametes and embryos. N Engl J Med 1988;318:828-34.

16. Rosenwaks Z. Donor eggs: their application in modern reproductive technologies. Fertil Steril 1987;47:895-909.

17. Polak de Fried E, Notrica J, Rubinstein $\mathrm{M}$ et al. Pregnancy after human donor oocyte cryopreservation and thawing in association with intracytoplasmic sperm injection in a patient with ovarian failure. 
Fertil Steril 1998;69:555-7.

18. Yang DS, Blohm PL, Winslow L, Cramer L. A twin pregnancy after microinjection of human cryopre-

served oocyte with a specially developed oocyte cryopreservation regime. Fertil Steril 1998;S 239:357.

19. Young E, Kenny A, Puigdomenech E et al. Triplet

pregnancy after intracytoplasmic sperm injection of cryopreserved oocytes: case report. Fertil Steril 1998;70:360-1.

20. Fabbri R, Porcu E, Marsella T et al. Human oocyte cryopreservation: new perspectives regarding oocyte survival. Hum Reprod 2001;16:411-6.

21. Boldt J, Cline D, McLaughlin, D. Human oocyte cryopreservation as an adjunct to IVF-embryo transfer cycles. Hum Reprod 2003;18:1250-5.

22. cdc.gov [homepage on the Internet]. Department of Health and Human Services. Center for Disease Control and Prevention. 2002 Assisted reproductive technology success rates. c2004-5 [updated 2005 Sep 15; viewed 2005 Oct 15]. Available from: http://www.cdc.gov/ART/ART02/index.htm. 23. Assisted reproductive technology in the United States: 2000 Results generated from the American Society for Reproductive Medicine/Society for Assisted Reproductive Technology Registry. Fertil Steril 2004;81:1207-20.

24. Glorious Qur'ān, Chapter 18:46.

25. Glorious Qur'ān 16:72.

26. Glorious Qur'ān 25:74.

27. Glorious Qur'ān 42:49-50.

28. Glorious Qur'ān 37:100-1.

29. Glorious Qur'ān 3:38.

30. Sahih Al-Bukhari, Book 79, Kitaab al-Tibb,
Chapter 1, Hadith 5354. [on-line] Available from:

http://www.muhaddith.org.

31. Glorious Qur'ān 25:54.

32. Kamali MH. Principles of Islamic Jurisprudence.

Islamic Texts Society. 3rd ed. Cambridge: United Kingdom; 2005.

33. Proceedings of the Islamic Organization of Medical Sciences. Conference, Cairo, Egypt, December 2004 (in Press).

34. Fadel HE The Islamic Viewpoint on New Assisted Reproductive Technologies. Fordham Urban Law Journal. 2002;30(1):147-57.

35. Fadel HE. Assisted Reproductive Technologies. An Islamic Perspective. In: Fadel HE, editor, FIMA Yearbook. Islamabad, Pakistan: Federation of Islamic Medical Associations and Medico Islamic Research Council; 2002. pp. 59-68.

36. Al-Abd OM. Islamic Organization for Medical Sciences. Islamic Law Ruling on Certain Medical Questions-The Argument and Supporting Evidence, 2004. [on-line] Available from: http://www.islamset.com/ioms/Code2004/Islamic_vision2.html. 37. Hathout M: Surrogacy. An Islamic Perspective. J Islam Med Assoc 1989;21:157-60.

38. Schenker JG, Frenkei DA. Medico-legal aspects of in vitro fertilization and embryo transfer practice. Obstet Gynecol Surv 1987;41:405-13.

39. Glorious Qur'ān 58:2

40. Glorious Qur'ān 16:78.

41. Glorious Qur'ān 39:6.

42. Glorious Qur'ān 46:15.

43. Glorious Qur'ān 33: 4-5. 